\title{
PELATIHAN MANAJEMEN BAGI PENGELOLA BADAN USAHA MILIK DESA (BUMDES) DAN IBU-IBU PKK DI KECAMATAN TEGALWERU DAU KABUPATEN MALANG
}

\author{
Mohammad Maskan ${ }^{1}$, Bambang Soepeno ${ }^{2}$, Tundung Subali Patma ${ }^{3}$, Yulis Nurul Aini ${ }^{4}$ \\ 1,2,3,4,5 Jurusan Administrasi Niaga, Politeknik Negeri Malang \\ email: ${ }^{1}$ mohammadmaskan@polinema.ac.id
}

\begin{abstract}
The goal of the local government is to provide some assistance to the villagers to stimulate the community to actively participate in local potential-based development. Therefore, BUMDes in an effort to strengthen the village economy based on the needs and potential of villages (agriculture), in order to increase the income and welfare of the villagers. The establishment of village-owned enterprises has several legal foundations that are the basis and reference in all its activities. The establishment of village-owned enterprises (BUMDes) is based on Law No. 32 of 2004 on Local Government and Government Regulation No. 72 of 2005 on Village Article 78. BUMDeS managers hold the key to success in its operationalization, therefore management training for BUMDeS managers supported by the PKK is urgently needed to improve the welfare of the villagers. This needs to be mastered by the managers of BUMDeS and PKK in order to manage their organizations through good planning, organizing, direction and supervision so that the organization's objectives can be achieved effectively and efficiently.
\end{abstract}

Keywords - management, effective, efficient

\section{PENDAHULUAN}

Dalam rangka peningkatan kesejahteraan ekonomi masyarakat, pemerintah daerah memberikan bantuan sejumlah dana kepada masyarakat desa guna merangsang masyarakat untuk ikut serta aktif dalam melaksanakan pembangunan. Oleh karena itu, desa memerlukan Badan Usaha Milik Desa (BUMDes) agar desa nantinya mampu meningkatkan pendapatan desa. Pendirian Badan Usaha Milik Desa memiliki beberapa landasan hukum yang menjadi dasar dan acuan dalam segala aktivitasnya. Pendirian Badan Usaha Milik Desa (BUMDes) dilandasi oleh Undang- Undang Nomor 32 Tahun 2004 tentang Pemerintahan Daerah dan Peraturan Pemerintah Nomor 72 tahun 2005 tentang Desa Pasal 78, Pemerintah Desa dapat mendirikan Badan Usaha Milik Desa (BUMDeS) haruslah didasarkan atau disesuaikan dengan kebutuhan dan potensi yang ada di desa. Semakin besar potensi yang dimiliki oleh suatu desa maka semakin besar pula peluang Badan Usaha Milik Desa untuk mengelolanya. Badan Usaha Milik Desa (BUMDes) adalah lembaga usaha desa yang dikelola oleh masyarakat dan pemerintah desa dalam upaya memperkuat perekonomian desa dan di bentuk berdasarkan kebutuhan dan potensi desa.

Tujuan pendirian Badan Usaha Milik Desa (BUMDes) yaitu untuk meningkatkan perekonomian desa, meningkatkan pendapatan asli desa dan meningkatkan pengelolaan potensi desa sesuai dengan kebutuhan masyarakat menjadi tulang punggung pertumbuhan dan pemerataan ekonomi desa. Dengan adanya Badan Usaha Milik Desa (BUMDes) akan menarik masyarakat sehingga secara perlahan angka kemiskinan akan menurun. 
Badan Usaha Milik Desa (BUMDes) yang ada di Desa Tegalweru Kecamatan Dau Kabupaten Malang merupakan badan usaha yang relatif baru sehingga belum memiliki kekuatan untuk mengelola usaha desa tersebut. Untuk itu, maka salah satu cara yang harus dilakukan oleh para pengelola adalah bagaimana memperkuat manajemen Badan Usaha Desa tersebut sehingga keberadaan usaha desa tersebut dapat meningkatkan kesejahteraan masyarakat yang ada di Desa Tegalweru Kecamatan Dau Kabupaten Malang tersebut. Kunci utama di dalam manajemen adalah man (orang) karena apek man ini akan sangat menentukan keberhasilan usaha desa ini. Salah satu cara untuk meningkatkan kemampuan pengelola usaha desa ini adalah dengan meningkatkan pengetahuan dan ketrampilan pengurus/pengelola usaha ini melalui pelatihan manajemen. Badan usaha desa dalam pengelolaan operasionalnya memerlukan pengelola yang baik. Manajemen secara sederhana diartikan sebagai cara bagaimana kita mendapatkan sesuatu melalui orang lain. Oleh karena itu, suatu organisasi, baik yang bersifat profit oriented maupun nirlaba ataupun pemerintah maupun swasta memerlukan manajer yang baik. Hal ini menjadi hal yang penting dengan alasan dua hal, yaitu, pertama, secara internal dengan pengelola (manajer) yang baik dapat mengelola sumberdaya yang dimiliki oleh perusahaan sehingga akan mencapai tujuan perusahaan secara efektif dan efisien. Adapun alasan kedua adalah bahwa secara eksternal persaingan bisnis semakin meningkat. Lebih-lebih kalau diingat bahwa daya saing perusahaan sangat ditentukan oleh kemampuan perusahaan menghasilkan produk yang memiliki competitive advantage sehingga

kelangsungan hidup dan pengembangan perusahaan dapat terjamin di masa mendatang.

Potensi yang dimiliki mitra untuk mengembangkan usahanya sebenarnya sangat besar. Hal ini disebabkan karena Badan Usaha Milik Desa (Bumdes) ini menyediakan kebutuhan barang yang diperlukan untuk usaha pertanian, dimana mayoritas (90\%) warga Desa Tegalweru berprofesi sebagai petani yang memerlukan barang-barang yang dibutuhkan untuk pertanian dan perkebunan, seperti: bibit, pupuk, bungkus produk yang sudah jadi, cangkul dan sejenisnya. Disamping itu juga
Bumdes dan PKK ini menyediakan usaha simpan pinjam bagi warga Desa Tegalweru, dimana lembaga ini ditujukan untuk membantu warga desa yang memerlukan dana untuk keperluan usahanya maupun untuk keperluan keluarga. Dengan demikian, potensi berkembangnya Bumdes ini sangat besar karena bidang usahanya sesuai kebutuhan masyarakatnya dan untuk memperolehnya tidak perlu birokrasi yang rumit, dekat dengan tempat tinggal dan harganya sangat terjangkau oleh masayarakat Tegalweru.

\subsection{Permasalahan Mitra}

Mengacu kepada analisa situasi di atas dan hasil diskusi dengan mitra, dimana masalah pengelolaan Badan Usaha Desa dan PKK belum dilakukan dengan efektif, jadi persoalan yang dihadapi oleh Bumdes dan PKK Tegalweru adalah:

a. Kurangnya kemampuan mereka di bidang pengetahuan dan manajemen usaha bagi pengelola Bumdes Tegalweru dan Ibu PKK. Hal ini disebabkan karena kebanyakan para pengelola Bumdes dan PKK Tegalweru memiliki latar pendidikan Sekolah Lanjutan Tingkat Atas (Sekolah Menengah Atas dan Sekolah Menengah Ketrampilan).

b. Belum memiliki pengalaman di bidang manajerial, sehingga ketrampilan manajemen usaha dan pelayanan masih minim.

\section{KAJIAN LITERATUR}

\subsection{Pengertian Manajemen Pengelolaan}

Pada suatu negara yang telah maju manajemen telah dapat memberi harapan harapan yang bisa menjelma dalam kenyataan. Mereka berusaha untuk membina dan mempertahankan kemajuan agar meningkat, bukannya stagnasi. Bagi Negara yang sedang berkembang mereka berusaha untuk menertibkan manajemennya agar diperoleh suatu perubahan yang revolusioner dalam aspirasi masyarakat, kestabilan politik, social dan budaya serta kedamaian dalam suatu kesatuan yang utuh.

Secara etimologis, manajemen berasal dari bahasa Perancis kuno ménagement, yang memiliki arti "seni melaksanakan dan 
mengatur." Sedangkan dalam bahasa Inggris manajemen berasal dari kata kerja "to manage" yang dalam bahasa Indonesia dapat berarti mengurus, mengemudikan, mengelola, menjalankan, membina, dan memimpin. Sama halnya dengan administrasi, kata manajemen juga berasal dari bahasa Latin, yaitu dari asal kata mantis yang berarti tangan dan agree yang berarti melakukan. Kata - kata itu digabung menjadi kata kerja manager yang artinya menangani. Managere diterjemahkan ke dalam bahasa Inggris dalam bentuk kata kerja to manage, dengan kata benda management, dan manager untuk orang yang melakukan kegiatan manajemen. Akhirnya, management diterjemahkan ke dalam bahasa Indonesia menjadi manajemen atau pengelolaan.

Brantas (2009:1-5) menyebutkan bahwa manajemen adalah penting untuk semua gerakan berhasilnya kegiatan dari suatu organisasi dalam mencapai tujuannya. Factor modal penggunaan teknologi adalah perlu bagi perkembangan dan pertumbuhan organisasi. Tetapi juga factor kecakapan dan keahlian manusia adalah lebih penting lagi sebab tak ada suatu organisasi pun dalam mengejar tujuannya bisa tahan lama tanpa manajer yang baik. Orang-orang inilah yang merencana, mengorganisasi, dan mengontrol pelaksanaannya.

Dalam suatu organisasi, peranan manajemen sangat dibutuhkan. Karena dengan manajemen yang baik secara keseluruhan akan mendukung fungsi daripada organisasi tersebut didirikan. Secara sederhana, Manajemen merupakan suatu proses tindakan atau seni perencanaan, mengatur, pengarahan dan pengawasan yang dinamis yang menggerakan organisasi mencapai tujuannya.

Manajemen merupakan suatu proses atau kerangka kerja, yang melibatkan bimbingan atau pengarahan suatu kelompok orang-orang kearah tujuan- tujuan organisasional atau maksud-maksud yang nyata. Manajemen adalah suatu kegiatan, pelaksanaannya adalah "managing" (pengelolaan), sedang pelaksanaannya disebut manajer atau pengelola. Manajemen menurut beberapa ahli yaitu:

a. G.R Terry " Manajemen adalah usahausaha untuk mencapai tujuan yang telah ditetapkan lebih dahulu dengan mempergunakan kegiatan orang lain. Buku: Principles of Management.

b. John D. Millett "Manajemen adalah proses pembimbingan, pengarahan serta pemberian fasilitas kerja kepada orang- orang yang diorganisir dalam kelompok jurnal untuk mencapai tujuan yang telah ditentukan. Buku: Management The Public.

c. Paul Hersey dan Kenneth H. Blanchard manajemen merupakan seni dan ilmu dalam perencanaan, pengarahan, pengorganisasian, pemotivasian, dan pengendalian terhadap orang dan mekanisme kerja untuk mencapai tujuan.

d. Mary Parker Follet (1997), manajemen adalah seni dalam menyelesaikan permasalahan yang terjadi dalam organisasi.

e. Ricky W. Griffin mendefinisikan manajemen sebagai suatu perencanaan, pengorganisasian, dan pengontrolan sumberdaya untuk mencapai sasaran secara efektif dan efisien. Efektif berarti tujuan dapat dicapai sesuai dengan perencanaan, sedangkan efisien berarti tugas yang ada dilaksanakan secara benar, terorganisasi, dan sesuai dengan jadwal.

f. James, manajemen adalah kebiasaan yang dilakukan secara sadar dan terus menerus dalam membentuk organisasi.

g. Dawam Rahardjo manajemen adalah suatu keahlian atau keterampilan (seni) untuk mencapai suatu tujuan produksi barang atau jasa yang dimiliki oleh seorang penguasa atau manejer.

h. Orday Tead (1951) "Management is procces and agency which direct and guides the operation of an organization in the realizing of established aim", (manajemen adalah proses dan perangkat yang mengarahkan, membimbing kegiatan-kegiatan suatu organisasi dalam mencapai tujuan yang telah ditetapkan).

i. Taylor manajemen adalah upaya menyelaraskan perencanaan, pengorganisasian, penggerakan staff, dan pengendalian atas semua aktivitas sehingga seluruh elemen organisasi 
mampu berinteraksi secara harmonis guna mencapai tujuan akhir organisasi.

j. Sofyan Assauri menjelaskan bahwa menejemen adalah sebutan yang sebenarnya mempunyai prinsip dan fungsi manajemenyang sama. Keduanya memberikan arahan agar bertindak sistematis dalam mencapai apa yang telah direncanakan dengan tepat, efektif dan efisien. Adapun yang menjadi ciri khas atau membedakan keduanya adalah bahwa manajemen itu berlaku untuk umum dan diterapkan dalam bidang apapun yang memerlukan aplikasi manajemen.

k. John G. Glover mendefinisikan manajemen sebagai kepandaian manusia menganalisa, merencanakan, memotivasi, menilai dan mengawasi penggunaan secara efektif sumbersumber manusia dan bahan yang digunakan untuk mencapai tujuan tertentu.

Dengan demikian

dapat disimpulkan bahwa manejemen berfungsi sebagai altifitas perencanaan (planning), suatu cara untuk mengendalikan atau pengorganisasian (organizing), penyusunan personalia atau kepegawaian (staffing), pengarahan dan kepemimpinan (coordinating), dan pengawasan (controling), untuk mencapai tujuan akhir. Jadi dapat disimpulkan bahwa manajemen adalah suatu proses yang menunjukkan pengelolaan dari fungsi- fungsi khusus atau spesifik (manajemen pemasaran , manajemen keuangan dan lainlain). Manajemen juga dimaknai sebagai ilmu, seni, karier, ataupun sebagai profesi.

Pengelolaan merupakan

terjemahan dari kata "management", istilah Inggris tersebut lalu di Indonesiakan menjadi "manejemen". Fungsi manejemen adalah aktivitas khusus menyangkut kepemimpinan, pengarahan, pengembangan, perencanaan, dan pengawasan terhadap pekerjaan dalam suatu proyek. Pengelolaan asal kata dari mengelola, sedangkan mengelola berarti menggadakan.

Sedangkan menggadakan adalah menganalisa dan mengaitkan berbagai informasi atau data untuk disajikan dalam bentuk yang dapat dipakai dan dimanfaatkan, sebagai upaya untuk mengatur atau mengendalikan aktivitas berdasarkan konsepkonsep dan prinsip- prinsip untuk mensukseskan tujuan agar tujuan tersebut tercapai secara lebih efektif dan efisien. Sedangkan dalam Kamus Bahasa Indonesia disebutkan bahwa pengelolaan berarti proses, cara atau perbuatan mengelola, sedangkan mengelola berarti mengendalikan atau menyelenggarakan.

Dengan demikian dapat disimpulkan bahwa pengelolaan adalah penyelenggaraan atau pengurusan agar sesuatu yang dikelola dapat berjalan lancar, efektif dan efisien. Manajemen adalah suatu rangkaian proses yang meliputi kegiatan perencanaan, pengorganisasian, pelaksanaan,

pengawasan, evaluasi, dan pengendalian dalam rangka memberdayakan seluruh sumber daya organisasi, baik sumberdaya manusia, modal, material, maupun teknologi secara optimal untuk mencapai tujuan organisasi.

Lahirnya konsep manajemen ditengah gejolak masyarakat sebagai konsekuensi akibat tidak seimbangnya pengembangan teknis dengan kemampuan sosial. Istilah manajemen telah diartikan oleh berbagai pihak dengan perspektif yang berbeda, misalnya pengelolaan, pembinaan, pengurusan, ketatalaksanaan, kepemimpinan, pemimpin, ketata pengurusan, administrasi, dan sebagainya.

\subsection{Fungsi Manajemen}

Sebelum menjalankan usaha agar tujuan mudah terealisasi tentunya diperlukan manajemen diatur sebaik mungkin, dan dijalankan melalui proses yang sistematis atau suatu rangkaian aktivitas yang satu sama lainnya saling bersusulan. Sesuai dengan fungsi manajemen yaitu elemen-elemen dasar yang selalu ada dan melekat dalam proses manajemen yang akan dijadikan acuan oleh menejer dalam melaksanakan kegiatan untuk mencapai tujuan.

Fungsi manajemen menurut Henry Fayol, antara lain: merancang, mengorganisasikan, memerintah, mengordinasikan, dan mengendalikan. Akan tetapi saat ini kelima fungsi tersebut diringkas menjadi empat fungsi pokok, yaitu:

\section{1). Perencanaan (Planning)}

Perencanaan adalah memikirkan apa yang akan dikerjakan dengan sumber yang daya yang 
dimiliki. Perencanaan dilakukan untuk menentukan tujuan perusahaan secara keseluruhan dan cara terbaik untuk memenuhi tujuan itu. Manajer mengevaluasi berbagai rencana alternatif dan menggunakan dugaan mengenai masa yang akan datang sebelum mengambil tindakan.

Perencanaan merupakan proses terpenting dari semua fungsi manajemen karena tanpa perencanaan, fungsi-fungsi lainnya tidak dapat berjalan seperti merealisasikan perencanaan dan pengawasan agar bisa mewujudkan tujuan yang direncanakan. Kemudian, melihat apakah rencana yang dipilih cocok dan dapat digunakan untuk memenuhi tujuan perusahaan. Dalam melakukan

perencanaan ada beberapa hal yang harus diperhatikan, antara lain sebagai berikut:
a. Hasil yang ingin dicapai
b. Orang yang akan melakukan
c. Waktu dan skala prioritas
d. Dana

\section{2). Pengorganisasian (Organizing)}

Pengorganisasian dilakukan untuk membagi suatu kegiatan besar menjadi kegiatan-kegiatan yang lebih kecil. Pengorganisasian mempermudah manajer dalam melakukan pengawasan dan menentukan orang yang dibutuhkan untuk melaksanakan tugas-tugas yang telah dibagibagi tersebut. Pengorganisasian dapat dilakukan dengan cara menentukan tugas yang harus dikerjakan, pekerjayang harus mengerjakannya, pengelompokan tugas-tugas tersebut, orang yang bertaanggung jawab atas tugas tersebut, dan tingkatan yang berwenang untuk mengambil keputusan. Akan tetapi bagi seorang muslim yang bertauhid ketika berorganisasi.

\section{3). Pengarahan (Directing)}

Pengarahan adalah suatu tindakan untuk mengusahakan agar semua anggota kelompok berusaha untuk mencapai sasaran sesuai dengan perencanaan manajerial dan usaha-usaha organisasi. Actuating artinya orang-orang agar bekerja dengan sendirinya atau penuh kesadaran secara bersama-sama untuk mencapai tujuan yang dikehendaki secara efektif. Dalam hal ini yang dibutuhkan adalah kepemimpinan. Pemimpin yang baik adalah pemimpin yang dapat mengarahkan bawahannya pada kebaikan. Selain amanah, ciri manajemen.

\section{4). Pengevaluasian (Evaluating)}

Pengevaluasian adalah proses pengawasan dan pengendalian performa atau kinerja perusahaan untuk memastikan bahwa jalannya perusahaan sesuai dengan rencana yang telah ditetapkan. Salah satu bentuk kesungguhan dalam manajemen usaha yaitu adanya evaluasi untuk mengetahui bagaimana hasil kerja yang kita peroleh, apakah meningkat atau tidak. Pada dasarnya manajemen usaha kecil tidak jauh berbeda dengan manajemen organisasi bisnis pada umumnya. Hanya saja jenis dan skala bisnis dari usaha yang dijalankan menyebabkan paling tidak ada beberapa faktor yang perlu dimiliki oleh mereka yang menjalankannya.

Diantara Faktor-faktor yang harus dimiliki oleh usaha kecil tersebut antara lain:

\section{5). Enterpreneurship (Kewirausahaan)}

Dalam prinsip-prinsip kewirausahaan adalah:

(1) Kreatif, Berani dan Percaya Diri; (2) Shiddiq yaitu benar dan jujur; (3) Tablig dan (4) Istiqamah. Adapun sikap yang harus dimiki manajer suatu usaha adalah:

1) Profesional

Profesional berarti usaha kecil dijalankan dengan menganut kepada prinsip-prinsip manajemen modern dalam organisasi. Dalam mengelola sumber daya manusia usaha kecil juga perlu menempatkan orang-orang yang sesuai dengan tempatnya. Jika perlu orang-orang dilatih agar dapat bekerja secara profesional. Pilihan bisnis juga didasarkan atas kemampuan dan daya jangkau para pelaku bisnis dalam usaha kecil tersebut. Dari segi keuangan, jika diperlukan, usaha kecil juga melakukan proses audit dari waktu ke waktu agar evaluasi atas keberhasilan usaha yang dijalankan juga bisa dilihat secara profesional.

2) Inovatif

Salah satu ciri-ciri dunia usaha adalah terjadinya perubahan yang begitu cepat. Perubahan tersebut dapat berupa perubahan dari karakteristik dan jumlah konsumen, jumlah pesaing, hingga 
ketersediaan pasokan bagi bisnis yang dijalankan. Berangkat dari hal tersebut usaha kecil perlu mengembangkan polapola inovatif dengan memunculkan berbagai ide baru mengenai pengembangan usaha yang dijalankan. Hal ini untuk memastikan agar usaha tidak hanya dapat bertahan ditengah-tengah perubahan, akan tetapi juga dapat berkembang sesuai dengan perubahan.

3) Keluasaan jaringan usaha

Pada dasarnya semakin luas jaringan yang dapat dibangun oleh usaha kecil, mulai dari jaringan pemasok, investor, pelanggan hingga berbagai pihak terkait, semakin besar peluang usaha kecil untuk mengembangkan usahanya dalam jangka panjang.

4) Kemampuan adaptif

Adaptasi juga diperlukan oleh usaha kecil dalam mengantisipasi berbagai perubahan yang terjadi secara internasional. Beberapa isu bisnis internasional seperti penerapan konsep internasional standard organization dan berbagai bentuk kesepakatan dalam teransaksi internasional juga menjadi suatu yang harus terus diikuti oleh para pengelola usaha kecil. Untuk tetap bisa bertahan dan meraih sukses dalam dunia bisnis dan bidang profesional lainnya, kerja keras, kesempurnaan manajerial dan stabilitas keuangan masih belum memadai karena kesuksesan bisnis juga tergantung pada kualitas produksinya.

5) Daya saing jaringan kerja

Seorang menejer mengelola suatu usaha harus sensitif terhadap semua aspekmanajemen terutama pada perencanaan, karena perencanaan merupakan hal yangterpenting dan tahap awal sebelum mengambil keputusan. Tanpa perencanaan maka usaha tidak bisa berjalan, begitu juga dengan fungsi manajemen yang lain seperti pengorganisasian, pengarahan dan evaluasi saling berhubungan antara satu sama lain. Keterkaitan tersebut membuat seorang manajer harus melakukan kegiatan sebaik mungkin sesuai tahapannya.

\subsection{Unsur-usur Manajemen}

\section{1) Man (Sumber Daya Manusia)}

Dalam manajemen, faktor manusia adalah yang paling menentukan. Manusia yang membuat tujuan dan manusia pula yang melakukan proses untuk mencapai tujuan. Tanpa ada manusia tidak ada proses kerja, sebab pada dasarnya manusia adalah mahluk kerja.

2) Money (Uang)

Uang merupakan salah satu unsur yang tidak dapat diabaikan. Uang merupakan alat tukar dan alat pengukur nilai. Besar-kecilnya hasil kegiatan dapat diukur dari jumlah uang yang beredar dalam perusahaan. Oleh karena itu uang merupakan alat (tools) yang penting untuk mencapai tujuan karena segala sesuatu harus diperhitungkan secara rasional. Hal ini akan berhubungan dengan berapa uang yang harus disediakan untuk membiayai gaji tenaga kerja, alat-alat yang dibutuhkan dan harus dibeli serta berapa hasil yang akan dicapai dari suatu organisasi.

\section{3) Materials (Bahan)}

Materi terdiri dari bahan setengah jadi (raw material) dan bahan jadi. Dalam dunia usaha untuk mencapai hasil yang lebih baik, selain manusia yang ahli dalam bidangnya juga harus dapat menggunakan bahan/materi-materi sebagai salah satu sarana. Sebab materi dan manusia tidaki dapat dipisahkan, tanpa materi tidak akan tercapai hasil yang dikehendaki.

\section{4) Machines (Mesin)}

Dalam kegiatan perusahaan, mesin sangat diperlukan. Penggunaan mesin 
akan membawa kemudahan atau menghasilkan keuntungan yang lebih besar serta menciptakan efesiensi kerja.

\section{5) Methods (Metode)}

Dalam pelaksanaan kerja diperlukan metode-metode kerja. Suatu tata cara kerja yang baik akan memperlancar jalannya pekerjaan. Sebuah metode daat dinyatakan sebagai penetapan cara pelaksanaan kerja suatu tugas dengan memberikan berbagai pertimbanganpertimbangan kepada sasaran, fasilitasfasilitas yang tersedia dan penggunaan waktu, serta uang dan kegiatan usaha. Perlu diingat meskipun metode baik, sedangkan orang yang

melaksanakannya tidak mengerti atau tidak mempunyai pengalaman maka hasilnya tidak akan memuaskan. Dengan demikian, peranan utama dalam manajemen tetap manusianya sendiri.

\section{6) Market (Pasar)}

Memasarkan produk sudah barang tentu sangat penting sebab bila barang yang diproduksi tidak laku, maka proses produksi barang akan berhenti. Artinya, proses kerja tidak akan berlangsung. Oleh sebab itu, penguasaan pasar dalam arti menyebarkan hasil produksi merupakan faktor menentukan dalam perusahaan. Agar pasar dapat dikuasai maka kualitas dan harga barang harus sesuai dengan selera konsumen dan daya beli (kemampuan) konsumen.

\subsection{Macam-macam Bidang Manajemen}

\section{1) Manajemen Pemasaran}

Pengertian manajemen pemasaran menurut Kotler atau Armstrong (2002:14), terjemahan Bakowatun menyebutkan bahwa : "manajemen pemasaran adalah analisis, perencanaan, pelaksanaan, dan pengendalian atas program yang dirancang untuk menciptakan, membangun, dan mempertahankan pertukaran yang menguntungkan dengan pembeli sasaran dengan maksud untuk mencapai tujuan maupun sasaran organisasi. Pengertian manajemen pemasaran menurut Buchari Alma (2004:130), yaitu: “manajemen pemasaran adalah merencanakan, pengarahan, dan pengawasan seluruh kegiatan pemasaran perusahaan atau organisasi dengan sub bagian atau bagian dipemasaran."

2) Manajemen Produksi

Handoko (2000:3) manajemen produksi dan operasi merupakan usaha-usaha pengelolaan secara optimal penggunaan sumber daya- sumber daya (atau sering disebut faktor-faktor produksi) tenaga kerja, mesin-mesin, peralatan, bahan mentah dan sebagainya, dalam proses transformasi bahan mentah dan tenaga kerja menjadi berbagai produk dan jasa.

3) Manajemen Keuangan

Pengertian Manajemen Keuangan menurut Brigham dan Houston yang diterjemahkan oleh Dodo, H. Dan Herman, W. (2001) yaitu "Manajemen keuangan merupakan bidang yang terluas dari tiga bidang keuangan, dan memiliki kesempatan karir yang sangat luas"

4) Manajemen Sumber Daya Manusia

Pengertian Manajemen Sumber Daya Manusia (MSDM) menurut Marwansyah (2010:3), manajemen sumber daya manusia dapat diartikan sebagai pendayagunaan sumber daya manusia di dalam organisasi, yang dilakukan melalui fungsi-fungsi perencanaan sumber daya manusia, rekrutmen dan seleksi, pengembangan sumber daya manusia, perencanaan dan pengembangan karir, pemberian kompensasi dan kesejahteraan, keselamatan dan kesehatan kerja, dan hubungan industrial. 


\subsection{Tingkatan dan Keahlian Manajemen}

Pada umumnya tingkatan manajer ada tiga, yaitu:

a. Top Manager (Manajer Puncak), yaitu tingkatan manajer tertinggi yang ada dalam suatu organisasi. Contoh top manager, misalnya: direktur utama, presiden (dalam suatu negara), menteri (dalam suatu departemen), gubernur (dalam level propinsi), bupati (dalam level kabupaten), Ketua, dan sejenisnya.

b. Middle Manager (Manajer Menengah), yaitu tingkatan manajer level menengah yang ada dalam organisasi. Contoh middle manager, misalnya: Direktur Pemasaran, Kepala Bagian, Kepala Biro, dan sejenisnya.

c. Lower Manager (Manajer Bawah), yaitu tingkatan manajer level bawah yang ada dalam organisasi. Contoh middle manager, misalnya: supervisor, super intendent, mandor, kasubag, ketua jurusan dan sejenisnya.

Sedangkan keahlian (Skills) yang harus dimiliki oleh seorang manajer adalah sebagai berikut:

a. Keahlian Teknis (Technical Skills), yaitu keahlian yang berkaitan dengan metode, peralatan dan teknis yang terlibat dalam melaksanakan tugastugas tertentu. Keahlian teknis ini contohnya misalnya: mengetik (untuk sekretaris), mengoperasikan komputer (tenaga administrasi), mengajar (untuk guru) dan sejenisnya.

b. Keahlian Manusiawi (Human Skills), yaitu keahlian yang berkaitan dengan kemampuan untuk bekerja secara efektif dengan orang lain. Keahlian manusiawi ini contohnya misalnya kemampuan kerja dalam kelompok, kemampuan berkomunikasi, kemampuan memotivasi orang lain dan sejenisnya.

c. Keahlian Konseptual (Conceptual Skills), yaitu keahlian yang berkaitan dengan kemampuan intelejensia, membuat perencanaan atau program, menganalisis situasi secara holistik dan sejenisnya.

\section{METODE PELAKSANAAN}

\subsection{Khalayak Sasaran}

Sasaran kegiatan ini adalah para Pengurus Badan Usaha Milik Desa (Bumdes) dan Pengurus Program Kesejahteraan Keluarga (PKK) di Desa Tegalweru Kecamatan Dau Kabupaten Malang. Untuk mendapatkan materi ini tentunya sangat penting bagi mereka. Hal ini untuk menyesuaikan dengan perkembangan ilmu manajemen yang sangat pesat, yang tentunya perlu dimanfaatkan untuk peningkatan efektivitas dan efisiensi pengelolaan organisasi mereka.

\subsection{Metode Pendekatan}

Metode pendekatan yang digunakan adalah dengan pendekatan praktis yang mengacu pada pokok permasalahan, yaitu peningkatan pengetahuan manajemen mitra. Adapun metode peningkatan pengetahuan manajemen adalah sebagai berikut:

a. Peningkatan Pemahaman tentang manajemen yang akan dilakukan dengan:

1) Mitra diberi ceramah singkat tentang konsep manajemen yang dilanjutkan dengan proses diskusi. Setelah itu mitra diminta merangkum secara tertulis pemahaman mereka tentang materi yang sudah dibahas. Hal ini dilakukan agar pemahaman mitra lebih baik karena ada proses pengulangan pemahaman yang berkali-kali.

2) Setelah itu diberi studi kasus manajemen untuk mencari solusi yang paling efektif dan jawaban dari masingmasing peserta pelatihan akan didiskusikan untuk meningkatkan pemahaman manajerial peserta pelatihan.

b. Peningkatan Pemahaman dan Ketrampilan tentang Fungsi Manajemen, yang akan dilakukan dengan:

1) Mitra diberi ceramah singkat tentang fungsi manajemen (perencanaan, pengorganisasian, pengarahan dan 
pengawasan) yang dilanjutakan dengan proses diskusi. Setelah itu mitra diminta merangkum secara tertulis pemahaman mereka tentang materi yang sudah dibahas. Hal ini dilakukan agar pemahaman mitra lebih baik karena ada proses pengulangan pemahaman yang berkali-kali.

2) Setelah itu diberi tugas penerapan fungsi manajemen untuk mencari solusi yang paling efektif dan jawaban dari masing-masing peserta pelatihan akan didiskusikan untuk meningkatkan pemahaman manajerial peserta pelatihan.

c. Peningkatan Pemahaman tentang Bidang Manajemen, yang akan dilakukan dengan:

1) Mitra diberi ceramah singkat tentang bidang manajemen (pemasaran, produksi, keuangan dan sumberdaya manusia) yang dilanjutakan dengan proses diskusi. Setelah itu mitra diminta merangkum secara tertulis pemahaman mereka tentang materi yang sudah dibahas. Hal ini dilakukan agar pemahaman mitra lebih baik karena ada proses pengulangan pemahaman yang berkali-kali.

2) Setelah itu diberi tugas penerapan bidang manajemen untuk mencari solusi yang paling efektif dan jawaban dari masing-masing peserta pelatihan akan didiskusikan untuk meningkatkan pemahaman manajerial peserta pelatihan

d. Penerapan Manajemen Organisasi

Pada tahap ini semua peserta pelatihan dapat menerapkan semua materi yang telah didapatkan dari pelatihan manajemen. Pada tahap ini dimungkinkan terjadi pemantauan dari tim PKM Politeknik Negeri Malang sehingga dapat dilakukan masukan untuk perbaikan dan peningkatan aplikasi manajemen di BUMDeS Tegalweru Kabupaten Malang sehingga kinerja para pengelola Bumdes pada akhir tahun 2020 semakin meningkat

\subsection{Partisipasi Mitra dalam Pelaksanaan Program}

Partisipasi mitra dalam pelaksanaan program adalah sebagai berikut :

a. Menyediakan tempat pelatihan

b. Menyediakan peralatan yang dibutuhkan selama kegiatan PKM, misalnya LCD, lap top dan lain-lain.

\subsection{Langkah Evaluasi Pelaksanaan dan Keberlanjutan Program}

a. Evaluasi Sebelum Kegiatan.

Sebelum melaksanakan kegiatan kita mengadakan observasi pendahuluan, untuk membuat persiapan dan uji coba, agar model pelatihan yang dirancang bisa diterima.

Tolok ukurnya :

Membuat suatu daftar pertanyaan, ditanyakan kepada peserta kemudian dievaluasi bisa ataukah tidak.

b. Evaluasi Selama Kegiatan.

Selama melakukan kegiatan kita evaluasi meliputi,

1) Evaluasi hambatan baik masalah penyampaian materi maupun hal- hal yang bersifat teknis

2) Evaluasi kelayakan materi yang diberikan.

3) Evaluasi daya penerimaan materi peserta/ penyerapan materi.

Tolok ukurnya :

Membuat suatu daftar pertanyaan, ditanyakan kepada peserta kemudian dievaluasi bisa ataukah tidak

c. Evaluasi terhadap Kemampuan Para Peserta.

Kemampuan peserta dievaluasi ke dalam kategori-kategori:

1) Peringkat I: peserta dianggap mempunyai kemampuan lebih.

2) Peringkat II: peserta dianggap mempunyai kemampuan rata-rata 
3) Peringkat III: peserta dianggap mempunyai kemampuan kurang

\section{d. Evaluasi Akhir Kegiatan.}

Evaluasi ini menilai faktor penghambat dan pendorong yang diperoleh dari awal sampai akhir kemudian dianalisa untuk mengetahui keberhasilannya.

\section{HASIL DAN PEMBAHASAN}

\subsection{Pelatihan Manajemen}

Memperhatikan latar belakang pengelola Bumdes dan PKK Tegalweru yang minim pengetahuan dan pengelolaan dalam mengelola usaha, maka solusi yang dapat dilakukan adalah sebagai berikut:

a. Melakukan pelatihan (workshop) tentang manajemen pengelolaan Bumdes bagi pengelola Bumdes dan PKK Desa Tegalweru Kecamatan Dau Kabupaten Malang. Materi pelatihan ini meliputi: Perencanaan, Pengorganisasian, Pengarahan dan Pengawasan. Disamping itu juga akan diberikan pelatihan tentang Manajemen Keuangan, Manajemen Pelayanan, Manajemen Pemasaran dan Manajemen Sumber Daya Manusia. Hasil dari pelatihan ini adalah agar para pengelola Bumdes dan PKK Tegalweru Kabupaten Malang agar dapat menerapkan model manajemen yang tepat, meningkatkan kompetensi para pengelola Bumdes dan meningkatkan efektifitas dan efisiensi dalam pengelolaan Bumdes.

b. Pendampingan penerapan manajemen dalam pengelolaan Bumdes. Tujuan pendampingan ini adalah untuk memperoleh masukan dalam upaya penyempurnaan alat dan pengelolaan Bumdes dan PKK Tegalweru Kabupaten Malang sehingga dapat mencapai tujuan secara optimal.

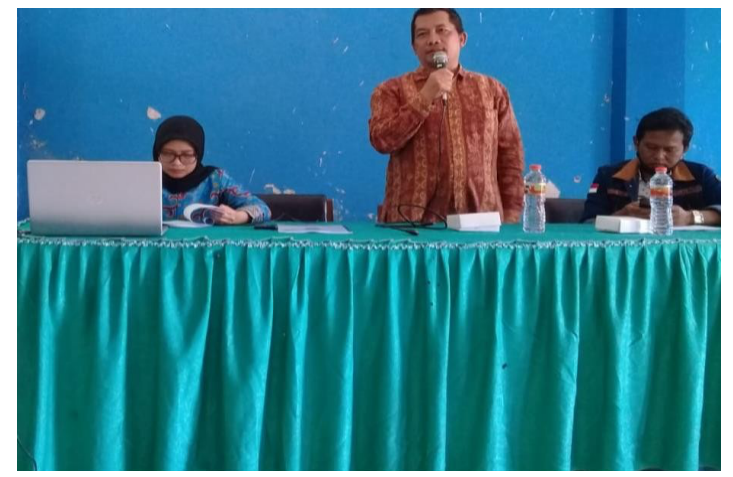

\subsection{Tujuan Pelatihan Manajemen}

Tujuan yang ingin dicapai dalam Pengabdian Kepada Masyarakat ini adalah meningkatkan kompetensi manajemen bagi para Pengurus Badan Usaha Milik Desa (Bumdes) dan Pengurus Program Kesejahteraan Keluarga (PKK) di Desa Tegalweru Kecamatan Dau Kabupaten Malang. Untuk mewujudkan tujuan tersebut diselenggarakan pelatihan kepada 7 orang Pengurus Badan Usaha Milik Desa (Bumdes) dan 10 orang Pengurus Pemberdayaan Kesejahteraan Keluarga (PKK) di Desa Tegalweru Kecamatan Dau Kabupaten Malang.

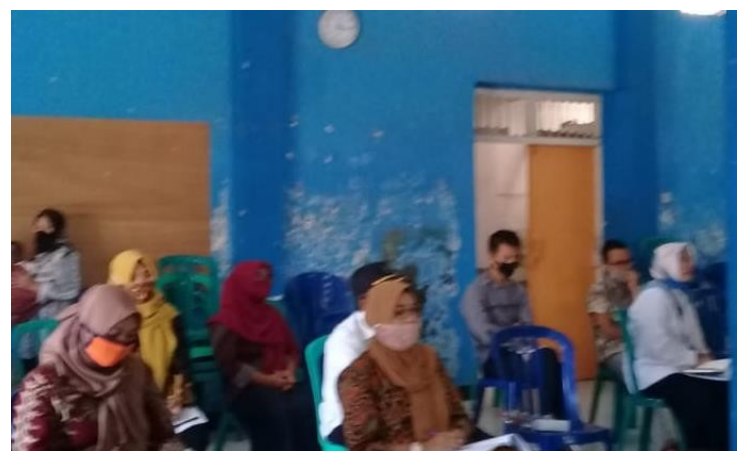

Dalam pelatihan secara umum diberikan dua materi utama, yaitu pengetahuan tentang teori Manajemen dan penerapannya untuk pengelolaan organisasinya. Untuk materi pertama, metode pembelajaran perlu disampaikan, mengingat pada penjajagan awal diketahui bahwa semua Pengurus Badan Usaha Milik Desa (Bumdes) dan Pengurus Program Kesejahteraan Keluarga (PKK) di Desa Tegalweru Kecamatan Dau Kabupaten Malang kebanyakan tingkat pendidikannya adalah Sekolah Lanjutan Tingkat Atas (SLTA) seperti Sekolah Menengah Atas (SMA) dan Sekolah Menengah Kejuruan (SMK) sehingga pengetahuan mereka tentang manajemen belum 
banyak mengetahui tentang manajemen dan prakteknya. Disamping itu, Badan Usaha Milik Desa (Bumdes) merupakan badan usaha baru yang dimiliki oleh desa dan merupakan program baru yang diluncurkan oleh Departemen Dalam Negeri (Depdagri) melalui Pemerintah Daerah (Pemda) Tingkat II Kabupaten Malang, dimana modal usahanya berasal dari Pemda Kabupaten Malang dan setiap akhir tahun harus dipertanggungjawabkan pengelolaan Bumdes kepada Pemda Kabupaten Malang. Selama ini dalam pengelolaan organisasi hanya berdasarkan kebiasaan dan budaya yang ada di masyarakat. Setelah mengadakan pengabdian kepada masyarakat, maka dalam melihat keberhasilannya harus dilihat dari hasil kegiatan tersebut. Saat ini memang harus diakui hasilnya belum begitu nampak. Tetapi berdasarkan hasil pengamatan selama ini tandatanda kearah itu sudah mulai ada.

Dengan adanya tingkat pengalaman bekerja yang hampir sama, maka dalam menyerap materi yang diajarkan hasilnya masih dapat dikatakan dapat terserap secara merata. Jadi secara umum dapat dikatakan secara keseluruhan materi yang diberikan dapat dimengerti oleh mereka. Seperti telah disebutkan sebelumnya peserta pengabdian masyarakat ini para yang mempunyai cukup pengalaman dan memiliki keinginan cukup besar untuk menambah pengetahuannya sehingga semakin mendorong keberhasilan pengabdian ini.

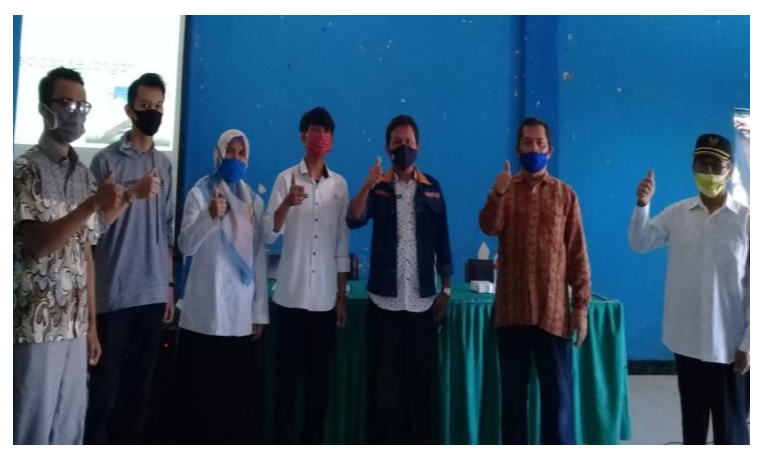

\subsection{Manfaat Pelatihan Manajemen}

Dengan pengabdian ini diharapkan para Pengurus Badan Usaha Milik Desa (Bumdes) dan Pengurus Pemberdayaan Kesejahteraan Keluarga (PKK) di Desa Tegalweru Kecamatan Dau Kabupaten Malang ini mampu: a. Meningkatkan penguasaan manajemen untuk mengelola organisasinya.

b. Meningkatkan efektifitas dan efisien dalam pengelolaanorganisasinya di era global

Keberhasilan pengabdian pada masyarakat ini belum dapat dilihat secara langsung, hal ini akan terlihat dalam peningkatan pengelolaan kepada organisasi di masa yang akan datang. Namun jika dilihat dari hasil yang dicapai maka manfaatnya adalah dengan bertambahnya pengetahuan dan wawasan yaitu dengan telah mendapat pengetahuan dan ketrampilan tentang manajemen untuk pengelolaan organisasi yang efektif dan efisien, sehingga diharapkan dengan adanya tambahan pengetahuan ini dapat membantu mereka dalam mengatasi berbagai masalah pengelolaan organisasi.

\subsection{Faktor Penghambat dan Pendukung Pelatihan}

\section{Faktor Penghambat Pelatihan}

Pelaksanaan kegiatan pengabdian pada masyarakat ini dirasa tidak ada faktor penghambat yang serius. Hal ini mengingat bahwa para peserta adalah para Pengurus Badan Usaha Milik Desa (BUMDeS) dan Pengurus Pemberdayaan Kesejahteraan Keluarga (PKK) di Desa Tegalweru Kecamatan Dau Kabupaten Malang Malang yang sudah cukup pengalaman dan mereka memang membutuhkan materi yang disampaikan.

\section{Faktor Pendukung Pelatihan}

Denganterselenggaranya pengabdian pada masyarakat ini dirasakan ada beberapa faktor pendorong yang menjadikan kegiatan ini dapat dilaksanakan dengan lancar, yaitu:

a. Minat dan semangat para peserta dalam mengikuti pelatihan sangat besar, sehingga mempermudah dalam proses belajar mengajar dan pemberian motivasi meskipun dalam kondisi yang sederhana.

b. Para pengurus Badan Usaha Milik Desa dan Pengurus PKK Desa Tegalweru Kecamatan Dau Kabupaten Malang mempunyai tekad besar untuk mencapai kemajuan sehingga dapat 
mendorong terlaksananya aktivitas pengabdian pada masyarakat ini.

c. Pengurus Badan Usaha Milik Desa dan Pengurus PKK Desa Tegalweru Kecamatan Dau Kabupaten Malang yang selalu terbuka dan siap menerima materi pelatihan sehingga memperlancar pelaksanaan kegiatan.

\section{Evaluasi}

Setelah selesainya kegiatan pengabdian pada masyarakat maka hasilnya dapat segera dievaluasi sebagai berikut :

\section{a. Relevansi}

Kegiatan ini sangat relevan diberikan kepada para Pengurus Badan Usaha Milik Desa (Bumdes) dan Pengurus Pemberdayaan Kesejahteraan Keluarga (PKK) di Desa Tegalweru Kecamatan Dau Kabupaten Malang. Mengingat mereka harus meng-update pengetahuan mereka dengan perkembangan ilmu manajemen agar tidak tertinggal dalam pengelolaan organisasinya.

\section{b. Akseptabilitas}

Materi Pengabdian Kepada Masyarakat yang diberikan mudah diterima dan dimengerti oleh peserta, karena materinya bersifat praktis.

\section{c. Efektifitas}

Pengabdian ini efektif mencapai tujuannya terutama bagi mereka yang mempunyai daya kreativitas yang tinggi.

\section{d. Ketepatan}

Ketrampilan yang diberikan sangat tepat sekali, karena mudah dipelajari dan berguna sebagai bekal di masa mendatang.

\section{e. Kegunaan}

Materi ini sangat berguna untuk mengantisipasi kondisi di masa mendatang, yang berhubungan dengan mengembangkan tugas pokok mereka sebagai pengelola organisasi publik.

\section{f. Pengaruh Jangka Panjang}

Akan membawa kemajuan di lingkungannya dalam rangka mensukseskan pengelolaan berbasis ilmu manajemen.

\section{g. Daya Ulang dan Kreativitas}

Untuk dapat menerapkan manajemen ini dengan lancar dan baik, harus selalu diadakan latihan yang serius dan kontinyu agar bekal ketrampilan yang telah diberikan terus berkembang.

\section{SIMPULAN}

Kegiatan pengabdian pada masyarakat telah selesai dilaksanakan dan dapat diambil beberapa kesimpulan yaitu :

a. Pengabdian ini adalah merupakan kegiatan untuk memperoleh tambahan keterampilan dan pengetahuan serta aplikasi dalam rangka meningkatkan efisiensi dan efektivitas pengelolaan organisasi.

b. Motivasi peserta sangat tinggi, hal ini terlihat dari antusiasnya peserta mengikuti sampai akhir program.

c. Hasil pengamatan selama proses kegiatan ini berlangsung maka dapat dilihat bahwa rata-rata penerimaan materi yang disampaikan oleh instruktur cukup baik.

d. Untuk lebih meningkatkan ketrampilan yang telah diperoleh maka perlu kiranya para peserta untuk lebih banyak berlatih dan mulai menerapkan dalamproses pengelolaan organisasinya.

\section{SARAN}

- Agar pengetahuan, ketrampilan dan aplikasi yang telah diberikan tidak hilang, maka perlu kiranya bagi Ketua Pengurus Badan Usaha Milik Desa dan Ketua Pengurus PKK Desa Tegalweru Kecamatan Dau Kabupaten Malang untuk memotivasi para anggotanya agar dapat berlatih dan mulai menerapkan manajemen dalam proses pengelolaan tugas-tugasnya.

- Untuk lebih banyak memperdalam dan memperoleh keterampilan yang mendukung kemajuan pengelolaan organisasi di Badan Usaha Milik Desa dan PKK Desa Tegalweru Kecamatan Dau Kabupaten Malang maka perlu kiranya 
ditingkatkan kerja sama dengan Politeknik Negeri Malang, khususnya sehubungan dengan kegiatan pengabdian pada masyarakat.

- Dengan selesainya kegiatan pengabdian pada masyarakat ini diharapkan agar lebih mempererat hubungan dan kerja sama antara Pengurus Badan Usaha Milik Desa (Bumdes) dan Pengurus PKK Desa Tegalweru Kecamatan Dau Kabupaten Malang dengan Politeknik Negeri Malang.

\section{DAFTAR PUSTAKA}

http://pengantarmanajemen.edublogs.org/20

11/10/15/fungsi-operasionalmanajemen/

Handoko, Hani T. 2003. Manajemen Personalia dan Sumber Daya Manusia. Edisi Kedua. Yogyakarta: BPFE Yogyakarta.

Hasibuan, Malayu, S.P. 2009. Manajemen Dasar, Pengertian, dan Masalah.
Cetakan Keenam. Jakarta: PT Bumi Aksara

Hariandja, Marihot Tua Efendi. 2000.

Manajemen Sumber Daya Manusia. Cetakan Pertama. Yogyakarta: PT Grasindo.

Martoyo, Susilo. 2000. Manajemen Sumber Daya Manusia. Edisi Keempat, Yogyakarta: BPFE - Yogyakarta.

Maskan, Mohammad, 2003, Manajemen untuk Sekretaris, Politeknik Negeri Malang.

Suandy, Erly, 2003, Perencanaan Pajak, Edisi Revisi, Penerbit : Salemba Empat, Jakarta 